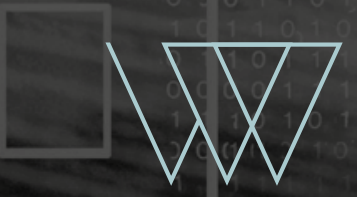

PAT

VESTUDIES IN LIFE

$W_{R / T} / N_{G}$

EMMA MAGUIRE

\title{
GIRLS,
}

AUTOBIOGRAPHY,

MEDIA

Gender and Self-Mediation

in Digital Economies

SERIES EDITORS: CLARE BRANT AND MAX SAUNDERS

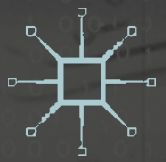




\title{
Palgrave Studies in Life Writing
}

\author{
Series Editors \\ Clare Brant \\ Department of English \\ King's College London \\ London, UK \\ Max Saunders \\ Department of English \\ King's College London \\ London, UK
}


This series features books that address key concepts and subjects, with an emphasis on new and emergent approaches. It offers specialist but accessible studies of contemporary and historical topics, with a focus on connecting life writing to themes with cross-disciplinary appeal. The series aims to be the place to go to for current and fresh research for scholars and students looking for clear and original discussion of specific subjects and forms; it is also a home for experimental approaches that take creative risks with potent materials.

The term 'Life Writing' is takenbroadly so as to reflect the academic, public and global reach of life writing, and to continue its democratic tradition. The series seeks contributions that address contexts beyond traditional territories - for instance, in the Middle East, Africa and Asia. It also aims to publish volumes addressing topics of general interest (such as food, drink, sport, gardening) with which life writing scholarship can engage in lively and original ways, as well as to further the political engagement of life writing especially in relation to human rights, migration, trauma and repression, sadly also persistently topical themes. The series looks for work that challenges and extends how life writing is understood and practised, especially in a world of rapidly changing digital media; that deepens and diversifies knowledge and perspectives on the subject, and which contributes to the intellectual excitement and the world relevance of life writing.

More information about this series at http://www.palgrave.com/gp/series/15200 


\section{Emma Maguire}

\section{Girls, Autobiography, Media}

Gender and Self-Mediation in Digital Economies 
Emma Maguire

James Cook University

Townsville, QLD, Australia

Palgrave Studies in Life Writing

ISBN 978-3-319-74236-6

ISBN 978-3-319-74237-3 (eBook)

https://doi.org/10.1007/978-3-319-74237-3

Library of Congress Control Number: 2018934696

(C) The Editor(s) (if applicable) and The Author(s) 2018

This work is subject to copyright. All rights are solely and exclusively licensed by the Publisher, whether the whole or part of the material is concerned, specifically the rights of translation, reprinting, reuse of illustrations, recitation, broadcasting, reproduction on microfilms or in any other physical way, and transmission or information storage and retrieval, electronic adaptation, computer software, or by similar or dissimilar methodology now known or hereafter developed.

The use of general descriptive names, registered names, trademarks, service marks, etc. in this publication does not imply, even in the absence of a specific statement, that such names are exempt from the relevant protective laws and regulations and therefore free for general use. The publisher, the authors and the editors are safe to assume that the advice and information in this book are believed to be true and accurate at the date of publication. Neither the publisher nor the authors or the editors give a warranty, express or implied, with respect to the material contained herein or for any errors or omissions that may have been made. The publisher remains neutral with regard to jurisdictional claims in published maps and institutional affiliations.

Cover illustration: Nanette Hoogslag / Alamy Stock Photo

Printed on acid-free paper

This Palgrave Macmillan imprint is published by Springer Nature The registered company is Springer International Publishing AG

The registered company address is: Gewerbestrasse 11, 6330 Cham, Switzerland 
This book is dedicated to all of the girls and young women who, despite it all, insist on taking up space. 


\section{ACKNOWLEDGEMENTS}

A shorter version of Chap. 4 appeared in Biography 38.1 (2015); thanks to Lucinda Rasmussen for her extremely valuable editorial comments on that version of the research. This work was helped greatly by funding received from the Faculty of Education, Humanities and Law at Flinders University to support my travel to Banff, Canada to attend the International Auto/ Biography Association (IABA) conference in 2014. The faculty and Flinders University both helped to fund a research field trip that I undertook in 2014 to several zine archives in the US, for which I am grateful.

I have been fortunate to have the support of many others in the process of writing this book.

Thanks to Camille Davies, Ben Doyle, and all at Palgrave Macmillan. To Clare Brant and Max Saunders for our short but valuable conversations at IABA conferences, and also for their work as editors of the Palgrave Studies in Life Writing Series.

Thanks to Esther Fan, Sara Fan, Olivia Park, Andrew Smales, Jenna Mourey, and Alex Wrekk for giving permission to reprint their images here.

The IABA community: I owe so much to the wonderful, generous scholars who make this field what it is. Especial thanks to Craig Howes for his exemplary leadership-I have never met such an inclusive, tireless, giving, and incisive scholar: we are so lucky to benefit from your knowledge and experience. To Julie Rak for her leadership, encouragement, support, and for her scholarship which has been so incredibly influential on my work and thinking. To all of the people who watched, asked questions, and offered feedback on conference papers that developed research for 
this book, thank you. I would like to offer particular thanks to Paul Arthur, Ash Barnwell, Ricia Chansky, Cynthia Franklin, Rob Gallagher, Emily Hipchen, Claire Lynch, Joel Haffner, Laurie McNeill, and Nicole Matthews. And to the organisers of these conferences: Julie Rak (IABA 2014), AmyKaterini Prodromou (IABA 2016), Kate Douglas and Kylie Cardell (IABA Asia-Pacific 2015), Donna Lee Brien (IABA Asia-Pacific 2017), and Clare Brant and Max Saunders (IABA Europe 2017), thank you for all of the work put in by you and your teams. These conferences have been so important and so special.

Thanks also to excellent postgraduates and early career researchers in the IABA community, especially: Ana Horvat, Daniel Juckes, Ümit Kennedy, Sarah McRae, Olga Michael, Marie O'Rourke, Leila Pazargadi, Astrid Rasch, Rachel Spencer, Daniella Trimboli, and Alex Winder.

To my collaborators and friends Maria Faini and Orly Lael Netzer: I feel so lucky to have been part of creating something special with you both. You each continue to inspire and motivate me to do good work and fight the good fight. My greatest hope is that we continue to find excuses to work together for many years to come.

To the Flinders Life Narrative Research Group for many workshops, writing lock-ins, and events that contributed to shaping this research.

To Tully Barnett and Son Vivienne for organising events that I feel very lucky to have taken part in. To Larissa Hjorth for her considered and useful feedback on an early iteration of my research on camgirls.

To Julia Watson for her detailed comments and recommendations on an early version of this project. To John Zuern, for your invaluable feedback and encouragement, and your continued generosity and support. You are truly one of the good guys. To Anna Poletti, who gave extensive and valued feedback and advice, particularly in the early stages of writing, and for whose insightful and incisive conversation I am incredibly grateful. Anna, we are so lucky in Auto/Biography Studies, to have your ideas and your voice to move discussion forward.

Kylie Cardell's support and enthusiasm for this project has been a vital source of encouragement, and I am grateful for her intellectual rigour which has improved my thinking, writing, and this research.

Lauren Butterworth, Alicia Carter, and Melanie Pryor: without you, academia (and life) would be much less fun and interesting. I am continually awed and inspired by you remarkable women. I can't thank you enough for your friendship and for all of our conversations which have helped shape my ideas and clarify my thinking about gender and culture. 
I cannot adequately express my profound gratitude for the mentorship, wisdom, generosity, support, and friendship of Kate Douglas, from whom I have learned so much.

To my family: your love, hearty encouragement, and belief in my capabilities has meant the world to me.

And at last, to my strongest ally and fiercest supporter, Simon Gould, for everything. There are no words that can describe what your support means to me and no scale that can measure the impact you have had on my life and work. Thank you. 


\section{Contents}

1 Introduction: Girls, Autobiography, Media

2 Camgirls: Surveillance and Feminine Embodiment in Lifecasting Practice

3 Negotiating the Anti-Girl: Articulating Punk Girlhood in the Online Diary

4 Self-Branding and Hotness in the YouTube Video Blogs of Jenna Marbles

5 Fangirling as Feminist Auto Assemblage: Tavi Gevinson and Participatory Audienceship

6 Sad Asian Girls and Collaborative Auto Assemblage: Mobilising Cross-Platform Collective Life Narratives

7 Eyebrows on What? Girls and Viral Economies 
xii CONTENTS

8 Hoaxing Instagram: Amalia Ulman Exposes the Tropes of \#Instagirlhood

9 Conclusion

Index 


\section{LisT OF Figures}

Fig. 3.1 Many of Wrekk's zines are half-size zines like this one. They allow space to play with the intersection of visual and textual elements (Image Brainscan \#21 appears here with thanks to Alex Wrekk)

Fig. 3.2 Screenshot of DiaryLand's interface in 2017. Things haven't changed much since the year 2000 (Image reproduced with thanks to Andrew Smales)

Fig. 4.1 The thumbnail image for Mourey's (2010) video plays on demand for both beauty tutorials and images of attractive young women (Image appears here courtesy of Jenna Mourey)

Fig. 4.2 Video still from "How to Trick People into Thinking You're Good Looking". Mourey uses humour to layer her audience's perception of who she is (Image appears here courtesy of Jenna Mourey)

Fig. 4.3 "About Me" on the Jenna Marbles website. Textual and visual signs combine to construct the Jenna Marbles self-brand (Image appears here courtesy of Jenna Mourey)

Fig. 6.1 Video still from "Have You Eaten?" Olivia and Esther each appear on video, playing themselves. Their visual representations consume food as the video plays, but also restrictive norms. The off-camera voice asks "You've gained weight, haven't you?" (Image appears here courtesy of Esther Fan and Olivia Park) 
Fig. 6.2 Activists gather at MoMA to protest, via performance art, the absence of work by Asian women artists (Image appears here courtesy of Sara Park)

Fig. 8.1 The Instagram profile presents an opportunity for automediality. Importantly, the narrative constructed here is coaxes visual representations due to the dominance of the profile grid 